\title{
DETERMINAN INVESTMENT OPPORTUNITY SET DAN FREE CASH FLOW SEBAGAI PEMODERASI
}

\author{
Elan Kurniawan \\ Fakultas Ekonomi dan Bisnis Universitas Islam Ass-Syafiiyah \\ Elan.kurniawan26@gmail.com
}

\begin{abstract}
The purpose of this study is to examine sales growth, earning growth, asset growth influence the Investment opportunity set with free cash flow as a moderating retail trade company listed on the Indonesia Stock Exchange. This type of research is quantitative research, with the population used are all retail trading companies listed on the Indonesia Stock Exchange during the year ie between 2014 and 2017 as many as 11 companies.

The sampling technique using purposive sampling method with data analysis techniques, namely multiple linear regression equations with hypothesis testing using SPSS. Based on the results of hypothesis testing, it shows that the sales growth variable has a significant positive effect on the Investment opportunity set but the profit growth and asset growth variable has no significant effect on the Investment opportunity set while the free cash flow moderates significantly positive on the sales growth of the Investment opportunity set.
\end{abstract}

Key word: IOS, SG, EG, AG and FSF

\begin{abstract}
Abstrak : Tujuan penelitian ini adalah untuk menguji pertumbuhan penjualan, pertumbuhan laba, pertumbuhan aset berpengaruh terhadap Investment opportunity set dengan free cash flow sebagai pemoderasi pada perusahaan retail trade yang terdaftar di Bursa Efek Indonesia. Jenis penelitian yang digunakan adalah penelitan kuantitatif, dengan populasi yang di gunakan adalah semua perusahaan perdagangan eceran yang terdaftar di Bursa efek Indonesia selama tahun pengamatan yaitu antara tahun 2014 sampai 2017 sebanyak 11 perusahaan.

Teknik pengambilan sampel dengan metode purposive sampling dengan teknik analisis data yaitu persamaan regresi linear berganda dengan pengujian hipotesis menggunakan SPSS. Bedasarkan hasil pengujian hipotesis menunjukan bahwa variabel pertumbuhan penjualan berpengaruh positif signifikan terhadap Investmen opportunity set tetapi variabel pertumbuhan laba dan pertumbuhan aset tidak berpengaruh signifikan terhadap Investme opportunity set sedangkan free cash flow memoderasi positif signifikan pada pertumbuhan penjualan terhadap Investment opportunity set.
\end{abstract}

Kata kunci: IOS, Pertumbuhan penjualan, Pertumbuhan laba, Pertumbuhan aset dan Free cash flow 


\section{PENDAHULUAN}

Setiap perusahaan pasti mengharapkan dan mengupayakan adanya suatu pertumbuhan dan perkembangan perusahaan seperti yang telah digariskan dalam visi dan misi perusahaan. Perusahaan yang sudah go public akan berusaha untuk memaksimumkan potensi perusahaan dengan jalan meningkatkan kesejahteraan para pemegang saham, memanfaatkan kesempatan investasi yang ada dengan benar serta memilih jenis investasi yang benar agar dapat memberikan kontribusi yang positif bagi perkembangan dan pertumbuhan perusahaan.

Persaingan peluang investasi pada sektor perusahaan retail menunjukan grafik yang fluktuatip dan cenderung semakin ketat ditandai dengan bertambah kuantitas investasi asing terhadap perusahaan retail seperti terpapar pada data grafik 1.1 berikut ini:

Grafik 1.1

Persentase rata-rata pertahun Investmen Opportunity Set (perusahaan Retail Trade yang terdaftar di Bursa Efek Indonesia periode 2014-2017)

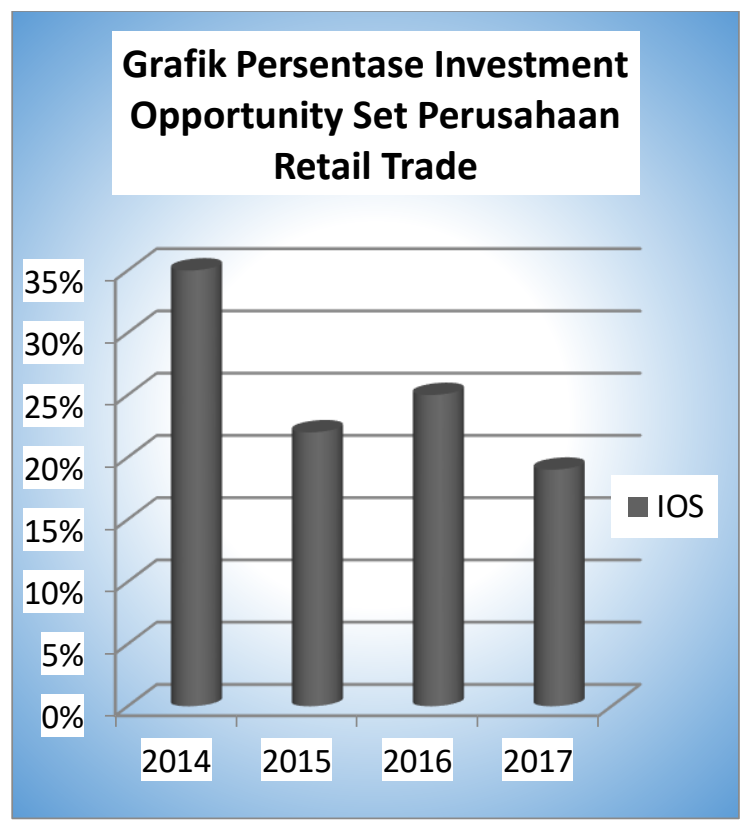

Pada grafik diatas, tahun 2014 persentase peluang investasi perusahaan retail menunjukan nilai persentase $35 \%$ yang lebih besar dibanding tahun-tahun berikutnya hal tersebut mencerminkan persaingan bisnis tahun ke tahun sektor retail trade semakin ketat, setelah mengalami penurunan 22\% tahun 2015 pada tahun 2016 mengalami kenaikan sebesar 25\% dan pada tahun 2017 mengalami penurunan kembali menjadi 19\% sehingga Investment opportunity set sangat menarik untuk diteliti demikian juga terhadap faktor-faktor yang mempengaruhinya.

Set kesempatan investasi merupakan peluang untuk memafaatkan sumber daya perusahaan untuk melakukan ekspansi maupun pengelolaan sumber daya manusia dengan sebaik-baiknya. (Suratno dan Hotma BP. : 2014).

Menurut Bringham dan Houston (2010), Bagi perusahaan dengan tingkat penjualan dan laba yang tinggi kecenderungan perusahaan tersebut menggunakan sumber dana eksternal yang lebih besar dibandingkan perusahaan-perusahaan yang tingkat penjualannya rendah. 
Pertumbuhan laba merupakan kenaikan laba yang dimiliki perusahaan dibandingkan dengan laba tahun sebelumnya. Rumus Pertumbuhan Laba yaitu (Indriyani: 2015)

Menurut Kasmir (2017:114-115) Rasio pertumbuhan (growth ratio) merupakan rasio yang menggambarkan kemampuan perusahaan dalam mempertahankan posisi ekonominya di tengah pertumbuhan perekonomian dan sektor usahanya.

Penelitian yang dilakukan Ayulestari et al. (2014) terbukti pertumbuhan penjualan berpengaruh terhadap keputusan pendanaan berbeda juga dengan penelitian yang dilakukan Endiana I. D., et al (2012) Rata-rata pertumbuhan penjualan pada tahap awal memperlemah hubungan antara investment opportunity set dengan kebijakan dividen tunai.

Ayulestari et al (2014) menemukan bahwa terdapat hubungan yang signifikan antara pertumbuhan aset dengan keputusan pendanaan perusahaan manufaktur, Senada dengan penelitian yang dilakukan oleh Ria Octavia (2012) juga menemukan bahwa pertumbuhan aset berpengaruh signifikan terhadap opsi investasi Investment Opportunity Set.

Hasil dalam penelitian Hotma B. P. dan Suratno (2014) menunjukan bahwa variabel Profitabilitas (pertumbuhan laba) terbukti tidak berpengaruh terhadap set kesempatan investasi bertentangan dengan hasil penelitian Octavia R. (2012) menunjukkan bahwa pertumbuhan laba berpengaruh secara signifikan terhadap opsi investasi IOS.

Analisis data yang dilakukan Oleh Putri D. A. (2010) memperoleh hasil bahwa variabel free cash flow tidak berpengaruh signifikan terhadap investment opportunity set sedangkan penelitian Gultom dan Afriani S. (2011) free cash flow mempunyai pengaruh signifikan terhadap kebijakan utang perusahaan.

Dari ulasan penelitian terdahulu pada beberapa variabel yang diuji memberikan hasil yang berbeda mengenai variabel pertumbuhan penjualan, pertumbuhan aset dan pertumbuhan laba tehadap Investment opportunity set. Dengan konteks waktu penelitian dan objek atau sampel yang diteliti berbeda, maka penelitian dapat menghasilkan kesimpulan yang berbeda. Perbedaannya yaitu pada kriteria pengambilan sampel penelitian ini berasal dari perusahaan Retail Trade yang mengeluarkan laporan keuangan selama periode pengamatan tahun 2014-2017.

Berdasarkan latar belakang tersebut diatas, maka rumusan masalah yang dikemukakan adalah sebagai berikut: apakah pertumbuhan penjualan, pertumbuhan laba dan pertumbuhan aset berpengaruh terhadap investment opportunity set dan free cash flow memoderasi pertumbuhan penjualan terhadap investment opportunity set?.

\section{KAJIAN LITERATUR}

\subsection{Investment Opportunity Set (IOS)}

Menurut Putri A. R. dan Adayani (2017) Kesempatan investasi adalah kesempatan investasi yang merupakan pilihan investasi dimas datang dan mencerminkan adanya pertumbuhan aktiva dan ekuitas.

Nilai kesempatan investasi merupakan nilai sekarang dari pilihan-pilihan perusahaan untuk membuat investasi di masa mendatang.

\subsection{Sales Growth}


Perhitungan tingkat penjualan pada akhir periode dengan penjualan periode dasar saat ini bisa dijadikan indikator dalam melihat pertumbuhan penjualan. Apabila nilai perbandingannya semakin besar, maka dapat dikatakan bahwa tingkat pertumbuhan penjualan semakin baik (Maryati D., 2014).

\subsection{Earning Growth}

Menurut Ikatan Akuntan Indonesia (2014), penghasilan bersih (laba) seringkali digunakan sebagai ukuran kinerja atau sebagi dasar bagi ukuran yang lain seperti imbalan investasi (return on invesment) atau penghasilan per saham (earnings per share). Pada umumnya kinerja manajer perusahaan diukur dan dievaluasi berdasarkan laba yang diperoleh.

\subsection{Asset Growth}

Aset adalah sumber ekonomi yang diharapkan memberikan manfaat kemudian hari. Aset merupakan aktiva yang digunakan untuk aktivitas operasional perusahaan. Semakin besar aset diharapkan semakin besar hasil operasional perusahaan. Peningkatan aset yang dikiuti peningkatan hasil operasi akan semakin menambah kepercayaan pihak luar terhadap perusahaan (Budiasa et al.: 2016).

\subsection{Free Cash Flow}

Pengertian lain menurut Brigham et al. (2014) adalah "free cash flow merupakan arus kas yang benar- benar tersedia untuk didistribusikan kepada investor setelah perusahaan tersebut melakukan investasi dalam aset tetap, produk baru, dan modal kerja yang digunakan untuk menjalankan dan mempertahankan aktivitas operasi perusahaan yang sedang berjalan. Free cash flow sebagai aliran kas yang tersedia untuk dibagikan kepada para pemegang saham atau pemilik dalam bentuk dividen. Pembagian tersebut dilakukan setelah perusahaan melakukan investasi pada aset tetap (fixed asset) dan modal kerja (working capital) yang diperlukan untuk kelangsungan usahanya (Mariah, et al.: 2012).

\section{METODE PENELITIAN}

\subsection{Jenis dan Sumber Data}

Penelitian ini termasuk kedalam jenis penelitian kuantitatif yang mana data tersebut adalah data sekunder. Data sekunder merupakan sumber data penelitian yang diperoleh peneliti secara tidak langsung melalui media perantara. Data sekunder yang digunakan berupa data laporan keuangan hasil audit perusahaan yang terdaftar di Bursa Efek Indonesia dalam Indonesian Capital Market Directory (ICMD), dan situs BEI (www.idx.co.id) periode laporan keuangan tahun 2015-2018. Adapun subjek yang diteliti yaitu perusahaan-perusahaan yang termasuk dalam sektor penjualan Retail Trade (perdagangan eceran).

\subsection{Populasi}

Menurut Sugiyono (2010), Populasi adalah wilayah generalisasi yang terdiri atas obyek/subyek yang mempunyai kualitas dan karakteristik tertentu yang ditetapkan oleh peneliti untuk dipelajari dan kemudian ditarik kesimpulannya. Populasi yang digunakan dalam penelitian ini adalah seluruh perusahaan penjualan Retail Trade memenuhi kriteria yang terdaftar (listing) di Bursa Efek Indonesia (BEI) pada tahun 2015-2018. 


\subsection{Sampel}

Sampel adalah bagian dari jumlah dan karakteristik yang dimiliki oleh populasi tersebut. Karena keterbatasan dana, tenaga dan waktu, maka peneliti dapat menggunakan sampel yang diambil dari populasi itu. Apa yang dipelajari dari sampel itu, kesimpulannya akan dapat diberlakukan untuk populasi. Untuk itu sampel yang diambil dari populasi harus betul-betul representatif (mewakili) (Sugiyono, 2010).

Pengambilan sampel dalam penelitian ini adalah dengan teknik purposive sampling dengan tujuan untuk mendapatkan sampel yang representatif sesuai dengan kriteria sampel.

\subsection{Definisi Variabel dan Operasional Variabel Penelitian}

Variabel yang digunakan dalam penelitian ini adalah variabel dependen yang berupa investment opportunity set. Sedangkan variabel independennya adalah pertumbuhan penjualan, pertumbuhan aset dan pertumbuhan laba. Adapun definisi operasional dari variabel-variabel tersebut adalah sebagai berikut :

\subsubsection{Variabel Dependen (Y)}

Variabel Dependen disebut juga variabel terikat yang berarti variabel ini dipengaruhi variabel independen. Dalam penelitian ini investment opportunity set (IOS) yang menjadi variabel dependen merupakan nilai perusahaan sekarang dari pilihanpilihan perusahaan untuk membuat investasi di masa depan. proksi ini dinilai dengan jumlah lembar saham beredar dikalikan dengan harga penutupan saham kemudian dibagi jumlah modal.

\subsubsection{Variabel Independen}

\section{a. Pertumbuhan Penjualan $\left(\mathbf{X}_{1}\right)$}

Pertumbuhan penjualan adalah tingkat kenaikan jumlah penjualan dari tahun ketahun atau dari waktu-kewaktu. pengukuran pertumbuhan penjualan adalah dengan membandingkan penjualan pada tahun t setelah dikurangi penjualan periode sebelumnya terhadap penjualan pada periode sebelumnya kemudian hasilnya dikalikan dengan $100 \%$.

\section{b. Pertumbuhan Laba $\left(\mathbf{X}_{2}\right)$}

Laba bisa dipandang sebagai suatu ukuran efisiensi. Laba adalah suatu ukuran kepengurusan (stewardship) manajemen atas sumberdaya suatu kesatuan dan ukuran efisiensi manajemen dalam menjalankan usaha suatu perusahaan.

Pertumbuhan laba dihasilkan dari laba operasi tahun tertentu dikurangi laba operasi tahun sebelumnya kemudian dibagi laba perasi tahun sebelumnya lalu dikalikan dengan $100 \%$.

\section{c. Pertumbuhan Aset $\left(\mathbf{X}_{3}\right)$}

Pertumbuhan aset adalah tingkat kenaikan jumlah aset dari tahun ketahun atau dari waktu-kewaktu, pihak manajemen perlu menginventerisasi perkembangan aset yang terjadi dengan seksama untuk membuat perencanaan peluang pendanaan yang tepat sedini mungkin, variabel ini diproksikan dengan Aset Growth membahas mengenai tingkat pertumbuhan aset tahun ke-t dikurangi aset tahun sebelumnya dibagi dengan aset tahun sebelumnya.

\section{d. Free Cash Flow $\left(\mathbf{X}_{4}\right)$}


Variabel moderasi dalam penelitian ini adalah Free Cash flow $(F C F)$ terhadap pertumbuhan penjualan terhadap IOS. Variabel free cash flow diproksikan dengan $F C F$, free cash flow diperoleh dari aliran kas operasi dari tahun pengamatan dikurangi pengeluaran modal dan dikurangi modal kerja bersih pada tahun pengamatan yang sama dibagi dengan total aset perusahaan pada tahun pengamatan yang sama.

\section{HASIL DAN PEMBAHASAN}

\subsection{Hasil Uji Regresi Linier Berganda}

Menguji regresi linier berganda untuk mengetahui pengaruh variabel independen terhadap variabel dependen yaitu Realized Growth yang terdiri dari Sales growth (SG), Earnings growth (EG), Asset growth (AG), Cash flow operation dan variabel moderator terhadap variabel dependen Investment Opportunity Set (MBVE), berdasarkan pada tabel koefisien hasil olah SPSS yang tampak pada tabel Coefficient.

\subsection{Hasil Uji t (Uji Parsial)}

Uji t bertujuan untuk mengetahui pengaruh variabel independen secara individu yang terdiri dari Sales growth (SG), Earnings growth (EG), Asset growth (AG), Free Cash flow dan variabel moderator terhadap variabel dependen Investment Opportunity Set $(M B V E)$. Berikut ini adalah tabel Coefficients yang akan mendasari hasil uji $\mathrm{t}$ dari tiga tabel regresi tersebut secara parsial sebagai berikut:

Tabel 4.1

Coefficients $^{a}$

\begin{tabular}{|c|r|r|r|r|r|}
\hline \multirow{2}{*}{ Model } & \multicolumn{2}{|c|}{$\begin{array}{c}\text { Unstandardized } \\
\text { Coefficients }\end{array}$} & $\begin{array}{c}\text { Standardized } \\
\text { Coefficients }\end{array}$ & \multirow{2}{*}{$\mathrm{T}$} & \multirow{2}{*}{ Sig. } \\
\cline { 2 - 4 } & \multicolumn{1}{|c|}{$\mathrm{B}$} & Std. Error & Beta & & \\
\hline (Constant) &, 330 &, 040 & & 8,238 &, 000 \\
SG &, 682 &, 157 &, 730 & 4,334 &, 000 \\
EG &, 044 &, 068 &, 061 &, 642 &, 524 \\
AG &, 136 &, 099 &, 138 & 1,370 &, 179 \\
FCF &, 039 &, 090 &, 041 &, 432 &, 668 \\
SG.FC & 1,999 &, 250 & 1,340 & 8,004 &, 000 \\
\hline
\end{tabular}

Dependent Variable: MBVE 
Berdasarkan hasil output SPSS tabel di atas terdapat nilai $\mathrm{t}_{\text {hitung }}$ sales growth lebih besar dari pada nilai $t_{\text {tabel }}(4,334>2,03011)$ dengan tingkat signifikan dibawah 0,05 yaitu $0,000104, t_{\text {hitung }}$ earnings growth lebih kecil dari pada nilai $t_{\text {tabel }}(0,642<2,03011)$ dengan tingkat signifikan diatas 0,05 yaitu 0,524 , $\mathrm{t}_{\text {hitung }}$ asset growth kecil dari nilai $\mathrm{t}_{\text {tabel }}(1,370<2,03011)$ dengan tingkat signifikan diatas 0,05 yaitu 0,179 dan $\mathrm{t}_{\text {hitung }}$ Free Cash Flow lebih kecil dari pada nilai $\mathrm{t}_{\text {tabel }}(0,432<2,03011)$ dengan tingkat signifikan diatas 0,05 yaitu 0,668 dan thitung Pemoderasi (SG.FCF) lebih besar dari $t_{\text {tabel }}(8,008>2,03011)$ dengan tingkat sigifikan dibawah 0,05 yaitu 0,00000 . Berdasarkan cara pengambilan keputusan uji parsial dalam analisis regresi dapat disimpulkan sebagai berikut:

1. Variabel sales growth secara parsial berpengaruh positif signifikan terhadap peningkatan Investment opportunity set, sehingga $\mathrm{H}_{1}$ diterima.

2. Variabel earnings growth secara parsial berpengaruh positif tidak signifikan terhadap peningkatan Investment opportunity set. Sehingga $\mathrm{H}_{2}$ ditolak.

3. Variabel asset growth secara parsial berpengaruh positif tidak signifikan terhadap Peningkatan Investment opportunity set. sehingga $\mathrm{H}_{3}$ ditolak.

4. Variabel moderasi secara parsial berpengaruh positif signifikan terhadap peningkatan Investment opportunity set. sehingga $\mathrm{H}_{4}$ diterima.

\subsection{Hasil Uji Koefisien Determinasi $\left(\mathbf{R}^{2}\right)$}

Untuk mengetahui nilai variabel-variabel independen dapat menerangkan variabel dependennya maka koefisien determinasi $\mathrm{R}^{2}$ diselenggarakan, nilai yang digunakan adalah $R$ Square karena variabel independen yang digunakan dalam penelitian ini lebih dari dua buah variabel seperti pada tabel berikut:

Tabel 4.2

Model Summary

\begin{tabular}{|l|r|r|r|r|}
\hline Model & R & R Square & $\begin{array}{c}\text { Adjusted R } \\
\text { Square }\end{array}$ & $\begin{array}{c}\text { Std. Error of } \\
\text { the Estimate }\end{array}$ \\
\hline 1 &, $821^{\mathrm{a}}$ &, 673 &, 631 &, 13683 \\
\hline
\end{tabular}

Dari hasil pengolahan regresi berganda diketahui bahwa besarnya nilai koefisien korelasi (R) sebesar 0,673 artinya hubungan antar variabel independen Sales growth, Earnings growth dan Asset growth memiliki hubungan yang relatif kuat sebab berada di atas angka 0,5 sedangkan nilai koefisien determinasi berganda (Adjusted $R^{2}$ ) sebesar 0,631. Hal ini berarti bahwa variabel Sales growth, Earnings growth dan Asset growth mampu menjelaskan variasi dari variabel terikat, yaitu sebesar 67,3\% dan sisanya 32,7\% dipengaruhi oleh faktor-faktor lain di luar model penelitian, sedangkan standard Error of the Estimate sebesar 0,13683 menunjukkan model persamaan regresi secara tepat memprediksi variabel terikat.

Dengan demikian berarti variabel independen yang diwakili dengan Pertumbuhan penjualan, pertumbuhan laba, pertumbuhan aset dengan tambahan variabel Free cash flow ternyata hampir mencapai $70 \%$ dari $100 \%$ menjelaskan variabel dependen set peluang investasi (investmen opportunity set). 


\subsection{Pembahasan Hasil Penelitian}

\subsubsection{Hubungan Pertumbuhan Penjualan terhadap Investment Opportunity Set}

Subramanyam (2014 : 487) Pertumbuhan penjualan adalah analisis tren dalam penjualan berdasarkan segmen berguna dalam menilai profitabilitas, pertumbuhan penjualan sering merupakan hasil dari satu atau lebih faktor, termasuk perubahan harga, perubahan volume, akuisisi/divestasi, dan perubahan nilai tukar.

Dari pengujian yang dilakukan, menujukan bahwa pertumbuhan penjualan (sales growth) berpengaruh positif dan signifikan terhadap investment opportunity set menunjukan semakin besar pertumbuhan penjualan (sales growth) maka semakin besar peluang investasi masa depan (IOS). Hasil penelitian ini menunjukan bahwa dengan adanya pertumbuhan penjualan dari tahun ketahun menujukan tren positif (peningkatan kuantitas dan value penjualan) maka investor dengan melihat laporan laba/rugi komprehensip berprespektif adanya peluang investasi masa depan yang positif akan mendorong meningkatnya minat investasi, hal ini sejalan dengan hasil penelitian dari Oktavia R. (2012), tetapi berbeda dengan hasil penelitian Putri D. A. (2010) dan I Dewa, I Ketut dan I.B. Putra (2012).

Investor luar perusahaan tidak hanya melihat angka-angka yang tercantum pada laporan keuangan saja tetapi juga dapat melihat dari catatan atas laporan keuangan kemudian mempelajari poin-poin penjelasan tiap akun tiap tahun dan pada sektor usaha apa yang di jalani, prospek kedepan sektor usaha tersebut apakah akan terus bertumbuh cerah pada perusahaan retail trade yang diteliti, ternyata pada penelitian ini pertumbuhan penjualan berpengaruh positif dan signifikan mempengaruhi Investment Opportunity Set maka alasan pada kalimat tersebut dapat dimengerti untuk mendukung hasil penelitian pada variabel ini. Pertumbuhan penjualan menggambarkan nama baik perusahaan yang ditunjang keberhasilan promosi tepat tertarget dan terukur, ada pekerjaan berkelanjutan untuk mempertahankan prestasi penjualan bahkan dengan meningkatkan volume penjualan perusahaan agar terus berkembang.

Konsistensi pertumbuhan penjualan baik itu perlahan-lahan maupun signifikan mensyaratkan penjaminan penyediaan sumber daya yang proporsional baik itu bahan baku, tenaga kerja dan overhead jika dalam perusahaan pabrik (manufaktur), pada perusahaan dagang perlu penyediaan barang dagangan yang bermutu yang terjamin dan konsisten dapat diperoleh dari suplier, dan pada perusahaan jasa minimal perlu menjaga kepuasan pelangan yang sudah ada dengan demikian konsistensi pemanfaatan jasa terjaga tidak perlu ketempat lain utk memperoleh jasa yang sama, dengan perlahan akan mengalami peningkatan karena ada promosi geratis dari pelanggan yang puas atas pelayanan perusahaan ditambah dengan bantuan promosi resmi tepat guna untuk pertumbuhan pelanggan.

\subsubsection{Hubungan Pertumbuhan Laba terhadap Investment Opportunity Set}

Menurut Harahap (2011), Pertumbuhan Laba adalah rasio yang menunjukan kemampuan perusahaan meningkatkan laba bersih periode tertentu dengan periode sebelumnya.

Berdasarkan poin-poin dari tersebut maka laba usaha belum tentu bisa dikategorikan berpengaruh signifikan karena pertumbuhan laba bisa saja besar akan tetapi kewajiban yang besar pula sehingga tidak bisa meyakinkan bahwa dengan bertumbuhnya laba menandakan eratnya hubungan antara pertumbuhan laba dengan IOS karena investor akan melihat pertumbuhan laba tiaptiap tahunnya bukan hanya pada laporan laba ruginya saja tetapi melihat juga apakah meningkat konsisten dan meningkat tahun-ketahun atau tidak sehingga dapat diduga kuat perusahaan tersebut dapat meningkatkan labanya di masa mendatang atau malah dengan laba meningkat tetapi hutang juga meningkat, efisiensi biaya tidak sukses, bonus dan reward manajemen atas dan menengah yang terlalu besar, pengendalian intern atas tertib administrasi dan praktik akuntansi tidak berjalan sebagaimana mestinya, dan dividen yang tertunda dan periode jatuh tempo dibayarkan maka alibatnya laba yang dicanangkan tidak terjadi. 
Pertumbuhan laba merupakan suatu kenaikan laba atau penurunan laba per tahun yang biasanya dinyatakan dalam persentase (Irma, 2011). Apabila suatu perusahaan memiliki kesempatan untuk bertumbuh, maka perusahaan tersebut dapat meningkatkan labanya di masa mendatang, hal ini menunjukan bahwa laba yang dihasilkan merupakan laba yang berkualitas. Jadi semakin tinggi kesempatan perusahaaan untuk tumbuh dan berkembang maka semakin tinggi pula kepastian laba opportunitinya, akan tetapi manajemen perusahaan bisa mengatur laba yang diinginkan yang disebut manajemen laba, manajemen laba bisa dibenarkan selama itu tidak menyalahi standar akuntansi yang berlaku di Indonesia seperti menahan laba tahun ini untuk diterbitkan ditahun mendatang, sehingga menekan pembayaran pajak maka beban yang dikeluarkan kecil untuk pajak yang bermanfaat untuk menahan uang keluar demi kesempatan untuk dimanfatkan sebagai modal sebelum dikeluarkan beban pajak pada periode mendatang.

Pengujian penelitan ini menunjukan pertumbuhan laba (earnings growth) berpengaruh positif tidak signifikan terhadap investment opportunity set dengan demikian, artinya pertumbuhan laba yang tinggi tidak selalu diikuti oleh tingginya minatan dan peluang investasi hal ini mempunyai probabilitas laba perusahaan yang meningkat digunakan untuk membayar dividen, membayar utangutang usaha baik jangka pendek dan jangka panjang dan reward karyawan juga sangat perlu ditunaikan demi kemajuan usaha yang sustainabel, sehingga secara jangka pendek tidak berdampak terhadap IOS akan tetapi kinerja perusahaan mengalami peningkatan yang positif dan berdampak untuk jangka panjang, hal ini mendukung penelitian terdahulu yang dilakukan oleh Putri D. A. (2010), Vahid Taghizadeh K. and Lida A, (2013) dan Pradipta A. (2013) namun penelitian ini bertentangan dengan hasil Oktavia R. (2012) dan Suratno Hotma B. P. (2014) yang menyatakan profitabilitas atau laba tidak berpengaruh negatif dan signifikan terhadap investment opportunity set (MBVE).

\subsubsection{Hubungan Pertumbuhan Aset terhadap Investment Opportunity Set}

Semakin tinggi rasio pertumbuhan aset suatu perusahaan maka semakin baik pula keadaan perusahaan tersebut dan tingkat laba (profit) akan tinggi juga (Ihwandi dan Rizal 2017).

Suatu perusahaan yang sedang berada dalam tahap pertumbuhan akan membutuhkan dana yang besar. Karena kebutuhan dana makin besar, maka perusahaan akan lebih cenderung menahan sebagian besar pendapatannya dalam waktu yang lama, paling tidak dalam waktu satu tahun. Meskipun aset perusahaan terus bertambah nilai dan fisiknya, belum tentu menjamin atau berpengaruh kuat bahwa prospek perusahaan masa depan akan lebih baik karena aset ditambah hanya untuk mendukung meningkatnya operasional perusahaan yang diakibatkan meningkatnya volume penjualan sehingga menuntut bertambahnya volume persediaan demi memuaskan para pelanggan yang bertambah sedangkan pendapatan penjualan jumlahnya relatif tetap dengan periode sebelumnya karena terdapat pengeluaran yang meningkat pula misalkan masih terdapat pemborosan biaya-biaya pokok dan operasional perusahaan yang belum bisa di hemat.

Pengujian terhadap pertumbuhan aset pada penelitian ini menujukan bahwa pertumbuhan aset (asset growth) berpengaruh positif tidak signifikan terhadap investment opportunity set hal ini mempunyai probabilitas bahwa perusahaan retail trade cenderung dengan signifikannya pertumbuhan Aset maka kinerja perusahaan mengalami peningkatan yang berarti dengan adanya tambahan aset dan aset tersebut dimanfaatkan secara maksimal untuk kegiatan investasi dan produksi bagi perusahaan akan tetapi misalkan salah satu contoh digunakan membayar kewajiban kepada pihak ketiga, membayar sewa gudang dan gedung usaha jangka panjang dan kurang efisiennya biaya operasional, tetap saja meskipun penghasilan meningkat tetapi jika dilihat prospek masa depan belum menunjukan titik terang.

Semakin besar pendapatan yang ditahan dalam perusahaan, berarti semakin rendah dividen yang dibayarkan kepada pemegang saham. Rendahnya pembayaran dividen akan menjadikan perusahaan makin kurang menarik bagi investor. Tingkat pertumbuhan yang cepat mengidentifikasikan bahwa perusahaan sedang mengadakan ekspansi. Kegagalan ekspansi akan meningkatkan beban perusahaan, karena harus menutup pengembalian biaya ekspansi. Makin besar 
risiko kegagalan perusahaan, makin kurang prospektif perusahaaan yang bersangkutan. Apabila kurang prospektif maka menyebabkan para investor menjual sahamnya di perusahaan tersebut karena minat dan harapan para pemodal turun. Hal ini menyebabkan perubahan return saham yang besar yang berakibat pada Beta Saham perusahaan yang besar. Pertumbuhan Aset diprediksi akan mempunyai hubungan yang positif dengan Beta Saham. Hal ini dikarenakan bila presentase perubahan perkembangan aset dari suatu periode ke periode berikutnya tinggi, maka risiko yang ditanggung oleh pemegang saham menjadi tinggi pula. Begitu pula sebaliknya. Pertumbuhan Aset adalah rata-rata pertumbuhan kekayaan perusahaan. Bila kekayaan awal suatu perusahan adalah tetap jumlahnya, maka pada tingkat pertumbuhan aktiva yang tinggi berarti besarnya kekayaan akhir perusahaan tersebut semakin besar.

Hasil pengujian penelitian ini bertentangan dengan peneliti terdahulu yaitu Oktaviani R. (2012) menyatakan menyatakan Pertumbuhan aktiva (aset) berpengaruh signifikan terhadap opsi investasi Investment Opportunity Set (IOS) akan tetapi mendukung hasil penelitian Atmawati P. D. (2010) yang menyatakan bahwa pertumbuhan aset berpengaruh tidak signifikan terhadap Investmen opprtunity set.

\subsubsection{Hubungan Pertumbuhan Penjualan terhadap Investment Opportunity Set dengan Free Cash flow sebagai Pemoderasi}

Brigham (2014) mendefinisikan aliran kas bebas sebagai cash flow yang dihasilkan dari operasi bisnis yang sedang berjalan dan tersedia untuk didistribusikan kembali kepada pemegang saham. Pembagian kas tersebut dapat dianggap atau tidak akan mempengaruhi tingkat pertumbuhan perusahaan pada periode tahun tersebut. Oleh karena itu pengertian aliran kas adalah adanya dana yang berlebih, yang seharusnya didistribusikan kepada para pemegang saham, dan keputusan tersebut dipengaruhi oleh kebijakan manajemen. Kas biasanya menimbulkan konflik kepentingan antara manajer dan pemegang saham (Arieska dan Gunawan, 2011). Karakteristik pertumbuhan penjualan serupa dengan arus kas bebas yang didalamnya terdapat penjualan barang dagangan yang dapat menambah besarnya jumlah nilai pemasukan yang bersumber dari penjualan maupun jumlah arus kas dari aktivitas operasi yang bisa lebih membuat optimis investor bahwa perusahaan yang bersangkutan memiliki prospek untuk lahan investasi lebih baik di masa mendatang.

Kinerja dari perusahaan yang tinggi dalam penjualan dapat mengindikasikan nilai pemegang saham yang diwujudkan dalam bentuk return yang berkembang melalui dividen, harga saham meningkat dan perusahaan tersebut semakin diperhitungkan atau dengan langkah lain jika laba tidak dibagikan akan menjadi laba ditahan untuk diinvestasikan dalam periode depan meningkat.

Free cash flow merupakan pemoderasi parsial yang berhasil memoderasi variabel pertumbuhan penjualan terhadap investment opportunity set, selain itu masih ada lagi varibel parsial lain yang bisa dijadikan pemoderasinya misalnya kualitas laba, kualitas audit, kinerja keuangan SPM dan lain-lain, di dalam penelitian ini yang dipilih pemoderasinya adalah free cash flow yang menjadi alasan bahwa ada kesamaan karakteristik yang kuat dari dua variabel ini yaitu adanya komponen penambah berupa kas masuk yang bisa menambah jumlah penjualan pada petumbuhan penjualan dan jumlah aliran kas bebas yang bertambah pada variabel free cash flow dalam annual report akuntansi.

Hasil penelitian ini bertentangan dengan hasil penelitian Putri D. A. (2010) Free cash flow berpengaruh positif namun tidak signifikan terhadap investment opportunity set.

\section{SIMPULAN DAN SARAN}




\subsection{Simpulan}

Bedasarkan hasil analisis penelitian yang telah dilakukan dapat diambil kesimpulan sebagai berikut:

1. Sales Growth $(S G)$ secara parsial berpengaruh positif signifikan terhadap peningkatan Investment opportunity set sehingga $\mathrm{H}_{1}$ diterima, hal ini menujukan bahwa dalam periode penelitian ini banyak perusahaan yang menunjukan konsistensi laba dari tahun-ketahun, dengan konsistensi mayoritas perusahaan pertumbuhan penjualannya terus naik menandakan prospek yang baik untuk iklim investasi pada perusahaan tersebut masa kini dan mendatang.

2. Earnings Growth (EG) secara parsial tidak berpengaruh positif signifikan terhadap peningkatan Investment opportunity set, sehingga $\mathrm{H}_{2}$ ditolak. Hal ini mengindikasikan bahwa dengan meningkatnya laba perusahaan berdampak baik terhadap iklim investasi dengan sebagian alasanya bahwa: laba digunakan untuk membayar dividen, membayar utang dan reward karyawan sehingga secara jangka pendek tidak berdampak terhadap IOS.

3. Asset Growth (AG) secara parsial tidak berpengaruh signifikan terhadap peningkatan Investment opportunity set, sehingga $\mathrm{H}_{3}$ ditolak. Hal ini mengindikasikan dengan meningkatnya aset perusahaan teutama aset tetap belum tentu berdampak baik terhadap iklim investasi, dengan instrument aset ini hakikinya untuk mendukung pemanfaatan maksimal kegiatan investasi dan produksi.

4. Free Cash flow $(F C F)$ sebagai pemoderasi Pertumbuhan penjualan berpengaruh positif signifikan terhadap Investment Opportunity Set, sehingga $\mathrm{H}_{4}$ diterima. Maka dapat dibuktikan bahwa FCF perannya berfungsi sebagai pemoderasi pertumbuhan penjualan terhadap IOS yang berpengaruh signifikan. Di dalam free cash flow terdapat elemen penjualan yang merupakan elemem pertumbuhan penjualan, hal ini menandakan bahwa free cash flow dapat dioptimalkan sehingga efeknya bisa mengangkat efektifitas dan pengaruh pada pertumbuhan penjualan secara signifikan terhadap Investment opprtunity set. Variabel free cash flow berpengaruh positif signifikan sebagai interaksi partial moderasi, selain variabel moderasi $F C F$ masih ada pemoderasi lain untuk memoderasi antara pertumbuhan penjualan terhadap investment opportunity set, misalnya: kualitas laba, kualitas audit, kinerja keuangan Corporate Governance dan lain-lain.

\subsection{Saran}

Berdasarkan hasil analisis pembahasan serta beberapa kesimpulan tersebut maka dapat disampaikan saran sebagia berikut:

1. Dalam penelitian mendatang perlu menambahkan variabel fundamental maupun variabel ekonomi lainnya sebagai sebagai variabel independen, karena sangat dimungkinkan variabel lain yang tidak dimasukan dalam penelitian ini berpengaruh kuat terhadap Investment Opportunity Set (MBVE).

2. Menambahkan rentang waktu penelitian yang lebih panjang sehingga hasil yang diperoleh akan lebih dapat digeneralisasikan dan untuk memperluas penelitian serta menghasilkan analisis yang lebih baik.

3. Untuk penelitian selanjutnya sebaiknya menggunakan sampel yang berbeda dan tidak terbatas pada sektor retail trade saja sehingga nanti akan dapat menghasilkan kontribusi informasi yang lebih baik dan akurat untuk penelitian masa mendatang.

4. Penelitian selanjutnya selain menggunakan determinan terhadap Investment opportunity set sebaiknya juga memasukan faktor dan teknikal, agar dapat memberikan gambaran yang lebih akurat atas faktor-faktor yang mempengaruhi IOS.

5 .

\section{REFERENSI}

Aries, H. P. (2011). Valuasi Perusahaan Jakarta pusat. PPM. 
Aristantia, et all. (2015). Investment Opportunity Set dan Free Cash Flow Pada Tingkat Pembayaran Dividen Perusahaan Manufaktur. E-Jurnal Akuntansi. Vol. 11(1): 220-234.

Arieska dan Gunawan, (2011). Pengaruh Aliran Kas Bebas dan Keputusan Pendanaan Terhadap Nilai Pemegang Saham dengan Set Kesempatan Investasi dan Dividen Sebagai Variabel Moderasi. Jurnal Akuntansi dan Keuangan, vol. 13, no. 1, mei 2011: 13-23. Universitas Muhammadiyah Yogyakarta

Atmawati P. D. (2010) Pengaruh Cash Flow, Profitability, dan Company Growth Terhadap Investment Opportunity Set: Pengujian Atas Perusahaan Non Keuangan Yang Terdaftar Di Bursa Efek Indonesia Universitas Sebelas Maret Surakarta.

Ayulestari P. et al (2014), Analisis pengaruh pertumbuhan asset, profitabilitas, pertumbuhan penjualan dan kebijakan dividen terhadap keputusan pendanaan pada perusahaan manufaktur yang terdaftar di bursa efek Indonesia.

Brigham, E.F., dan Houston, J.F. (2014). Fundamentals of Financial Management, 14 th Edition, Nelson Sducation, ltd. Boston USA, ISBN 13: 978-1-285-86797-7

Budiasa I ketut et al. (2016). Pengaruh Risiko Usaha dan Struktur Modal terhadap Pertumbuhan Aset serta Profitabilitas pada Lembaga Perkreditan Desa di kabupaten Badung. E-Jurnal Ekonomi dan Bisnis Universitas Udayana 5.7 (2016): 1919-1952. ISSN: 2337-3067.

Dina Maryaty (2014), Pengaruh profitabilitas, kebijakan dividen, struktur aset dan pertumbuhan penjualan terhadap kebijakan hutang pada perusahaan manufaktur yang terdaftar di BEI periode 2008 - 2012, Jurusan Akuntasi, Fakultas Ekonomi, Universitas Maritim Raja Ali Haji Kepulauan Riau.

Endiana I. D M., I Ketut Budiartha dan I.B. Putra Astika (2012), Pengaruh pertumbuhan penjualan di setiap Siklus hidup pada hubungan ios dengan dividen Tunai, Magister Akuntansi Universitas Udayana, Bali, Indonesia.

Eka Oktarya, Lili Syafitri dan Trisnadi Wijaya (2015), Pengaruh Pertumbuhan Laba, Investment Opportunity Set, Leverage dan Ukuran Perusahaan Terhadap Kualitas Laba pada Perusahaan Manufaktur yang Terdaftar di BEI, STIE Multi Data Palembang.

Febry Larasati (2015), analisis pengaruh rasio profitabilitas, likuiditas, leverage, price to book value, dan ukuran perusahaan terhadap return saham pada perusahaan tekstil yang terdaftar di BEI, Fakultas Ekonomi dan Bisnis Universitas Sumatera Utara.

Fitriana Warap Sari (2015). Pengaruh struktur kepemilikan terhadap kinerja perusahaan dengan struktur modal sebagai pemoderasi, (STESIA) Surabaya, Jurnal Ilmu \& Riset Akuntansi Vol. 4 No. 8 (2015).

Ghozali, I. (2013). Analysis Multivariate dengan Progam IBM SPSS. 20, Universitas Diponegoro. Semarang.

Gultom dan Afriani S. (2011). Analisis pengaruh free cash flow dan struktur kepemilikan saham terhadap kebijakan hutang dengan IOS sebagai variabel moderasi. repository USU.co.id. MT Accounting (522).

Endiana I. D. et al (2012), Pengaruh pertumbuhan penjualan di setiap Siklus hidup pada hubungan ios dengan dividen Tunai, Magister Akuntansi Universitas Udayana, Bali, Indonesia.

Harahap, S. Sofyan. (2011). Analisis Kritis atas Laporan Keuangan. Jakarta : PT. Raja Granfindo Persada.

Hery. (2013). Akuntansi Dasar 1dan 2. Edisi Pertama. Grasindo, Jakarta. 
Indriyani, I. (2015). Pengaruh Rasio Keuangan Terhadap Pertumbuhan Laba Pada Perusahaan Pertambangan Yang Terdaftar di Bursa Efek Indonesia. Jurnal Manajemen dan Bisnis Sriwijaya, 13(3), 343-358.

Ihwandi dan Rizal, Lalu. (2017). Pengaruh Pengungkapan Corporate Social Responsibility (CSR) dan Pertumbuhan Aset terhadap Profitabilitas Perusahaan (Pada Perusahaan Manufaktur yang Terdaftar di BEI Tahun 2011-2015). Journal Ilmiah Rinjani Universitas Gunung Rinjani Vol. 5 No. 2 Tahun 2017.

Ikatan Akuntan Indonesia (IAI). (2016). Standar Akuntansi Keuangan. Jilid 1. Salemba Empat, Jakarta

Indonesian Capital Market Directory (ICMD), Tahun 2014.

Indonesian Capital Market Directory (ICMD), Tahun 2015.

Ikatan Akuntan Indonesia (2014), PSAK 2 Laporan Arus Kas, SAK efektif Per 1 Januari 2016, Jakarta: IAI

Irma, A. (2011). Pengaruh Investment Opportunity Set Dan Mekanisme Corporate Governance Terhadap Kualitas Laba Dan Nilai Perusahaan. Skripsi. Universitas Diponegoro. Semarang.

Karsam dan Yanalia S (2010), Pengaruh Pertumbuhan Ekuitas dan Pertumbuhan Laba Terhadap Investment Opportunity Set (Studi Empiris pada Industri Properti dan Real Estate di BEI Periode Tahun 2004-2008). USM.

Kasmir. (2017). Analisis Laporan Keuangan. Jakarta: PT. Raja Grafindo Persada

Kieso, Donald E. dan Jerry J. Weygandt. (2011). Intermediate Accounting. John Wiley and Sons, Inc. New York.

Kusuma A. I. D. M. (2012), Pengaruh Rasio-Rasio Keuangan Terhadap Pertumbuhan Laba pada Perusahaan Manufaktur yang Terdaftar di Bei, Fakultas Ekonomi, Universitas Mahasaraswatim Denpasar.

Lusiana R., Mufidah F. dan Habibah N. (2016), Pengaruh tingkant FCF terhadap IOS pada perusahaan Makanan dan Minuman yang terdaftar di BEI, Vol. 3 No. 2 ISSN 2407-6325 Hal. 83-88 STIE La Tansa Mashiro.

Mariah, L. Meythi dan R. Martusa. (2012). Pengaruh Profitabilitas Dan Kesempatan Investasi Terhadap Kebijakan Dividen Tunai Dengan Likuiditas Sebagai Variabel Moderating Pada Emiten Pembentuk Indeks LQ 45 (Perioda 2008-2010). Seminar Nasional Akuntansi dan Bisnis (SNAB). Universitas Kristen Maranatha.

Murni Prasetyaningrum. (2014). Profitabilitas dan Return Saham: Peran Moderasi Arus Kas Operasi dan Ukuran Perusahaan. Magister Akuntansi Fakultas Ekonomi, Universitas Sebelas Maret.

Octaviani R. (2012), analisis pengaruh pertumbuhan perusahaan terhadap investment Opportunity set pada perusahaan automotive yang terdaftar di Bursa efek Indonesia.

Pradipta Arya (2013). Pengaruh Kebijakan Hutang, Kebijakan Dividen, Asimetri Investasi dan Profitabilitas terhadap Probabilitas Pertumbuhan Ivestasi Perusahaan (IOS). Media Bisnis, STIE Trisakti.

Puspitasari, Novia Ayu dan Darsono. (2014). Faktor-faktor yang Berpengaruh terhadap Kebijakan Dividen. Diponegoro Journal of Accounting Volume 3, Nomor 2, Tahun 2014, Halaman 1-8.

Putri A. R. Andayani, (2017). Pengaruh kebijakan hutang, Provitabilitas, Likuiditas, dan kesempatan investasi terhadap kebijakan dividen, Jurnal Ilmu dan Riset Akuntansi, 6, 1-15. 
Putri, D. A. (2013). Pengaruh Invesmen Opportunity Set, Kebijakan Utang dan Ukuran Perusahaan Terhadap Kebijakan dividen. Jurnal Manajemen. Vol. 2(2): 11-22.

Puji A. (2014), Pengaruh Kepemilikan Manajerial, Leverage, Profitabilitas, Ukuran Perusahaan dan Investment Opportunity Set Terhadap Nilai Perusahaan, Universitas Negeri Padang.

Sari, R. F. (2010). Analisis Pengaruh Kepemilikan Manajerial, Kebijakan Utang, Profitabilitas, Ukuran Perusahaan, dan Set Kesempatan Investasi terhadap Kebijakan Dividen. Skripsi. Universitas Sebelas Maret. Surakarta.

Subramanyam. K. R, dan John J. Wild. (2014). Analisis Laporan Keuangan. Penerjemah Dewi Y. Jakarta: Salemba Empat.

Siswoyo H. (2011). Praktikum Metodologi Penelitian: Aplikasi Penelitian dengan SPSS, STIE Pengembangan Bisnis manajemen, Jakarta.

Sugiyono at all. (2010). Metode Penelitian Bisnis. Cetakan ke-14. Bandung Alfabeta.

Suratno dan Hotma B. Panggabean (2014), Faktor-Faktor Fundamental Keuangan Perusahaan dan Investment Opportunity Set Perusahaan Real Estate, Jurnal Riset Akuntansi dan Perpajakan, JRAP Vol. 1, No. 1, Juni 2014, hal 60 - 70 ISSN 2339 - 1545.

Vahid Taghizadeh Khanqah and Lida Ahmadnia (2013). The Impact of Capital Structure on Liquidity and Investment Growth Opportunity in Tehran Stock Exchange. Department of Accounting Univ. of Rep. Islamic Iran.

www.idx.co.id 